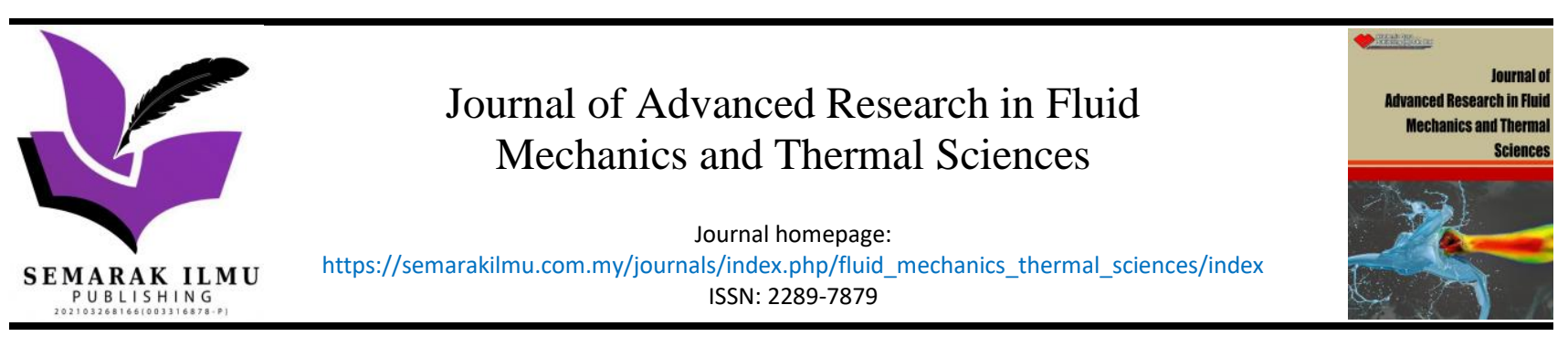

\title{
Hydraulic Model for Flood Forecasting of Tajabad Khwar in Hayatabad Phase III Peshawar, Pakistan: A Case Study
}

\author{
Mujahid Khan ${ }^{1}$, Uzair Ali ${ }^{2}$, Nayab Khan ${ }^{1}$, Sida Hussain ${ }^{1}$, Afnan Ahmad ${ }^{3, *}$ \\ Department of Civil Engineering, University of Engineering and Technology Peshawar, 25000, KPK, Pakistan \\ Local Government and Rural Development Department, Govt of KPK, Pakistan \\ Department of Civil and Environmental Engineering, Universiti Teknologi Petronas (UTP), Seri Iskandar, 32610, Perak, Malaysia
}

\section{ARTICLE INFO}

\section{Article history:}

Received 15 August 2021

Received in revised form 25 October 2021

Accepted 28 October 2021

Available online 27 November 2021

Keywords:

Hydraulic Model; Flood forecasting; Arc GIS; Flood mapping; Hydrological Modelling

\section{ABSTRACT}

Among all other natural disasters occurring throughout the world, floods are considered to be the worst and most devastating catastrophe as it causes loss of billions of lives. Flooding is caused due to inundation of water over the areas which are in close proximity of river or natural waterways resulting in severe damages to commercial and residential areas in the surrounding. Thus, an efficient flood forecasting system through the development of a combined hydrological and hydraulic model for the prediction of future flood events through marking the potential high-risk zone is required to minimize the damages. Due to large number of encroachments made in the waterway of Tajabad khwar located near Deans Residential Apartment of Hayatabad Phase III, a hydraulic model is developed for its flood forecasting as the floods in this khwar may cause severe damages to the inhabitants of the adjacent areas. In this research work, Flood zone maps are developed for 10 years, 20 years, 50 years, and 100 years flood return periods in order for deterring extent of the inundation as a result of these encroachments and to identify the areas at potential risk. Flood discharge for each return period was estimated using HEC-HMS software and was found to be $772,1036,1392$ and $1666 \mathrm{~m}^{\wedge} 3 / \mathrm{sec}$ for 10 years, 20 years, 50 years, and 100 years flood return periods respectively. The corresponding water surface elevation determine using HEC-RAS and was found to be $196 \mathrm{~m}, 197 \mathrm{~m}$, $201 \mathrm{~m}, 202 \mathrm{~m}$. This model provides a basic idea for developing flood zone maps of a given period of return for the assessment of areas that can get adversely pretentious by floods.

\section{Introduction}

The increasing damages caused by the floods become more severe in the most recent centuries as more than 3 billion lives get badly affected. Urban floods are considered to be more severe and unavoidable than all other natural disasters because they cause potential damage to the people living around that area. The main causes of floods include shorter and longer duration rainfall, obstruction to the flow of water, encroachment of the channel flow area, etc. [1,2].

The floods cause devastating damages to commercial and residential having adverse economic as well as environmental implications along with loss of human lives. With urbanization, the natural

\footnotetext{
* Corresponding author.

E-mail address: afnan_19001642@utp.edu.my
}

https://doi.org/10.37934/arfmts.89.1.160174 
waterways have encroached as people have started settling in river valleys, which have made flooding an unavoidable life-threatening danger for human communities. These days most of the losses causes to human life are due to flooding events on yearly basis. That's why it is very important to estimate and manage the flooding hazards, for minimizing the adverse consequences of floods [3]. It is very important to understand the varying nature of a water channel flow for assessing and anticipating the effects of high flows. For this purpose, one and two-dimensional hydraulic models are generally used. This type of models simulates the flood events and gives us information elevations of water surface and its path of flow, thus accordingly recognizing vulnerable zones. Marking of these zones helps to plan real-time management plans and helps to set some suitable measures in order to safeguard populated urban regions [4].

Floods are considered to be a manageable natural disaster as it follows a regular seasonal pattern. Due to this reason, the area under threat can be identified and the extent to which the flood may prevail can also be determined [5]. Numerous early flood warning techniques can be used, one of them is to describe flood phenomena using numerical techniques [6]. The type of modelling approach depends normally on the purpose of runoff estimation, presence of data, and the effective use of the present data [7]. HEC-HMS has become very popular and has been adopted by many researchers in different hydrological studies because of its ability to simulate the runoff both in short and long-time events, due to its simplicity use of common methods [8]. One dimensional hydrodynamic system approach is used to model waterways, streams, or channels. Such models are mostly developed on HEC-RAS and Mike 11 software [9]. The two-dimensional MIKE21 and Info Works 2D models are frequently applied to different rivers and floodplains. HEC RAS 5.0.7 is introduced by The United States (Army Corps of Engineers) that can be used for the 2-Dimensional hydraulic modelling [10].

When the quantity of rainfall exceeds the total drainage capacity of the channel, the water starts to overflow causing urban flooding [5]. So, the study of the complex relationship between rainfall and the runoff process is very important to properly estimate the quantity of water from any catchment area [11]. For surface runoff simulation Hydrologic Modelling System (HEC-HMS) was used for the GilgelAbay Catchment. Soil conservation services (SCS) methods were selected for losses and runoff estimation while the Muskingum method was used for flow routing. It was found that the HECHMS model performed better for peak flow and total volume estimation for GilgelAbay Catchment and other ungauged catchments [11].

Analysis of unsteady flow in an open channel is done using HEC-RAS software based on the St. Venant equation for routing a stage hydrograph. The inputs of this model are the channel crosssection geometry, flow discharge, and boundary conditions. The water surface profiles, flow hydrograph, and velocity flow distribution in cross-section along the drain are computed iteratively. Water surface computations are based on the newton Raphson method [12]. HEC-RAS can be used as a hydraulic (flood) analysis and flood plain determination. The results which are obtained through the HEC-RAS model can help in the determination of the extent to which overtopping of bridges/barrages will occur in the study reach when the given magnitude of the flood was implied to the model [13]. HEC-RAS was used for flood studies of the river Jhelum as different places in Kashmir were affected by floods. The previous peak flood data were used as inputs in the 1D hydraulic model to determine the expected flood levels. This model has effectively identified the area which is most likely to be affected by the future predicted floods [14].

In this research study, a hydraulic model was developed based on the predicted flood of Rio Rocha, Cochabamba, Bolivia. A study area of $17 \mathrm{~km}$ of river Rio Rocha and tributaries was used for the performance of the hydraulic simulation. The data used for the study include high-resolution Digital Elevation model (DEM) and computed hydrographs. Validation of the results was made through actual field observations. It was found that Iber could be used as a convenient tool to aid the decision 
processes required for the promotion of sustainable urbanization. Iber is a two-dimensional mathematical model for simulating free surface flow and environmental process in river hydraulics. Therefore, this study implied a renewed and more viable approach for assessing flood risk [15].

A combination of the HEC-RAS model with HEC-Geo RAS was used for the performance of hydrological and hydraulic modelling in order to identify the inundated area during heavy rainfall events for the Swat River basin for a flood with a return period of 100 -years. $45 \mathrm{~km}^{2}$ flood inundation was observed with a prediction of $25 \mathrm{~m}$ flood elevation[16]. An Integrated Flood Analysis System (IFAS) hydrologic modelling with a data set of GSMaP-NRT was used to minimize the damage caused by flood in river Kabul by taking countermeasures downstream. It was observed that discharge calculated was in a better synchronization with measured discharge while using the Satellite GSMaPNRT. The duration of the flood and its peak calculated by the Satellite GSMaP-NRT was also showing the best match with the observed data [17].

A study was conducted to develop a hydraulic model that will help in developing improved disaster risk management in Namibia. A study was conducted for 3 catchment areas of the Namibia River. A hydraulic model was developed using data including Digital Elevation model (DEM) and river geometry generated using Arc GIS. HEC-RAS model was developed for three different flow rates including $1030 \mathrm{~m}^{3} / \mathrm{s}, 600 \mathrm{~m}^{3} / \mathrm{s}$, and $100 \mathrm{~m}^{3} / \mathrm{s}$ collected from the past. Flood plains were developed in RAS mapper and are then exported to GIS format to overlay with infrastructural data. The model was validated by two methods, including field visit and satellite data [18].

Zoning of floods in the river cannot be achieved without hydraulic analysis. In this study, hydraulic analysis was performed for the determination of River flooding events using the HEC-RAS model. Determination of cross-section of the river was carried out Arc-GIS software with the help of (DEM) and HEC-Geo RAS (an extension of HEC-RAS) in order to inspect the results of the hydraulic model and for the determination of flood zone maps for 5, 10, 20, 50 and 100 years return periods [19].

In a recent research work under the area of analysis of risks and impact engineering, rheological model is developing to simulate and check the hazard that may be cause by debris flow in complicated routes. The suitability of different other models is also being check and it is concluded that the velocity and runoff is greatly affected by the difference of turbulent friction coefficient. Also it is concluded that a suitable model is necessary for understanding the complex nature of debris flow [20].

A research is carried out to determine the effect of scouring on bridge pier both experimentally as well as through model for the river Kabul Peshawar. The experimental results are compared with the results taken from simulation model of river analysis modelled through HEC-RAS. Ten experiments are performed using ten different values of flow and its depth on both circular as well as square piles. Both experimental as well as model results shows that the square piles will be more subjected to scouring if the discharge or flow changes but the difference in scouring of both circular as well as square piles decreases with a considerable increase in flow [21].

So, it is important to identify the area to be affected by the maximum possible flood so that mitigation measures can be adopted beforehand. As is clear from the literature presented, HEC-RAS can be used as an effective tool for such purposes. Secondly, the literature review reveals that research were carried out on rivers but there was no significant work done on natural waterways (khwar/Nullah) subjected to encroachment reducing the discharge carrying capacity and resulting in a flash flood. Therefore, in this study HEC-RAS model is applied to identify the areas to be affected by future floods in the study area. 


\section{Methodology}

To carry out the flood modelling of the study area using HEC-RAS the following methodology is adopted. This research mainly focuses on flood zone mapping of the Tajabad Khwar (Natural Waterway) adjacent to the Deans Apartment Building No 4 near Phase III Hayatabad Flyover, Peshawar through the development of the hydraulic model. The site is located at $33^{\circ} 59^{\prime} 43.61^{\prime \prime} \mathrm{N}$, $71^{\circ} 27^{\prime} 49.27^{\prime \prime} \mathrm{E}$. The calculated catchment area contributing to the khwar storm flood is $169.05 \mathrm{sq} \mathrm{km}$ (65.30 miles2) as shown in Figure 1. The longest stream length is found to be $34.31 \mathrm{~km}$ ( $21.31 \mathrm{miles}$ ) and the maximum and minimum elevation difference along the entire length of the longest stream is $1483 \mathrm{~m}$. The mainstream bed slope is $0.043 \mathrm{~m} / \mathrm{m}$ and the highest level of the catchment area plain is $1860 \mathrm{~m}$.

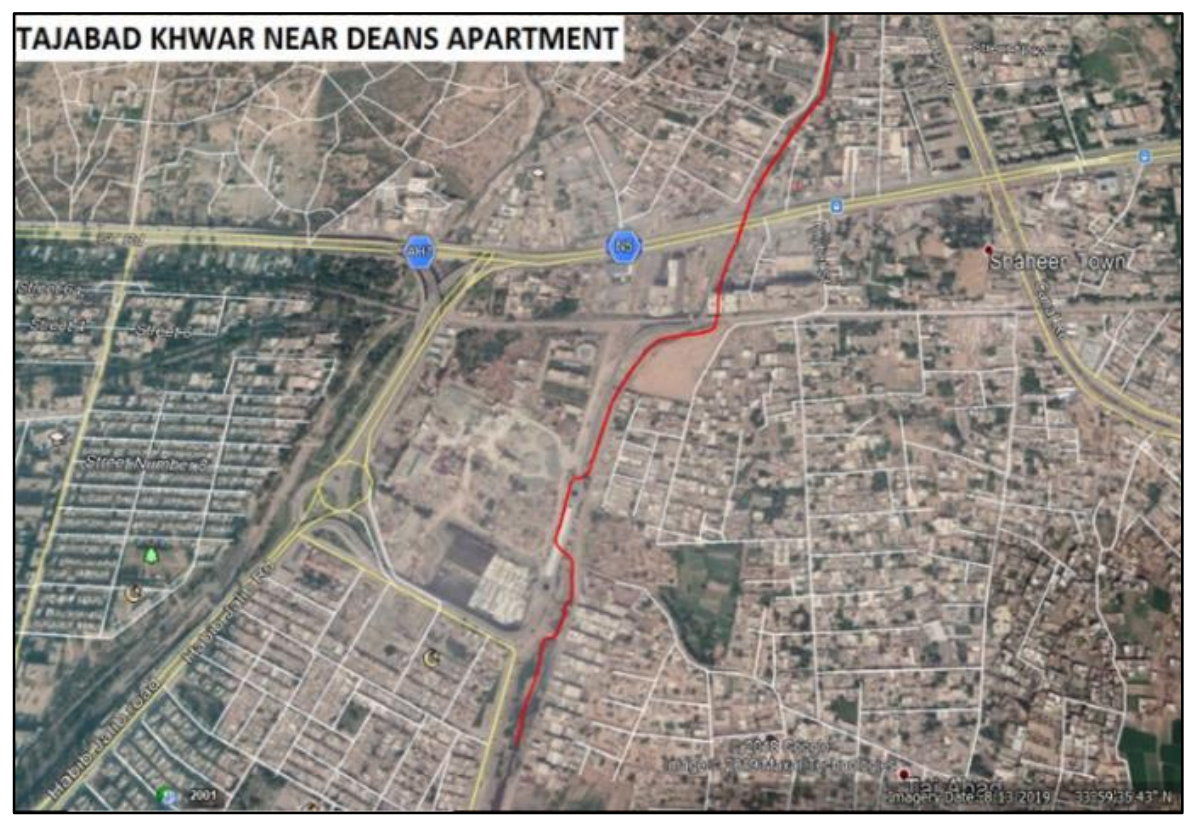

Fig. 1. Location map of study area

\subsection{Topographical Features of Study Area}

Since a topographic map for a specific site was not available, therefore survey was carried out by using Total Station and GPS along 1.5 KM reach of Nullah concluding at G.T Road Bridge near the Deans Apartment with reference to the Benchmark located at Tajabad Railway Bridge. From the topographic map so developed, 30 Nullah Cross-sections were developed. The overall data along with Digital Elevation model (DEM) was then transferred to CAD Civil 3D and Eagle Point using Data Module Transfer (DTM). The Data Module Transfer was used in the second module and an interval from $25 m-100 m$ is choose in order to prepare the plan/ profile of the Khwar (Natural Stream) bed and to plot the cross-section of the Khwar. This interval is based on the sudden and unexpected change in the longitudinal as well as horizontal plan of the Tajabad Khwar. The contours and profiles prepared are used for the performance of model and for the demarcation of the flooding zones on map. 


\subsection{Flood Discharge Estimation Using HEC HMS}

Since no flow data were available for the study area, therefore hydrological modelling via HEC HMS was used for the calculation of Flood Discharge. The required inputs for hydrological modelling include the watershed characteristics (obtained using Arc GIS and DEM), and rainfall data obtained from the Pakistan Meteorological Department (PMD) with a mean annual rainfall depth of $382 \mathrm{~mm}$ for the Peshawar rain gauge station. Moreover, the study area is mainly divided into build up area, irrigated area of ordinary crops, and grazing land under different seasons with better green cover as shown in Figure 2.

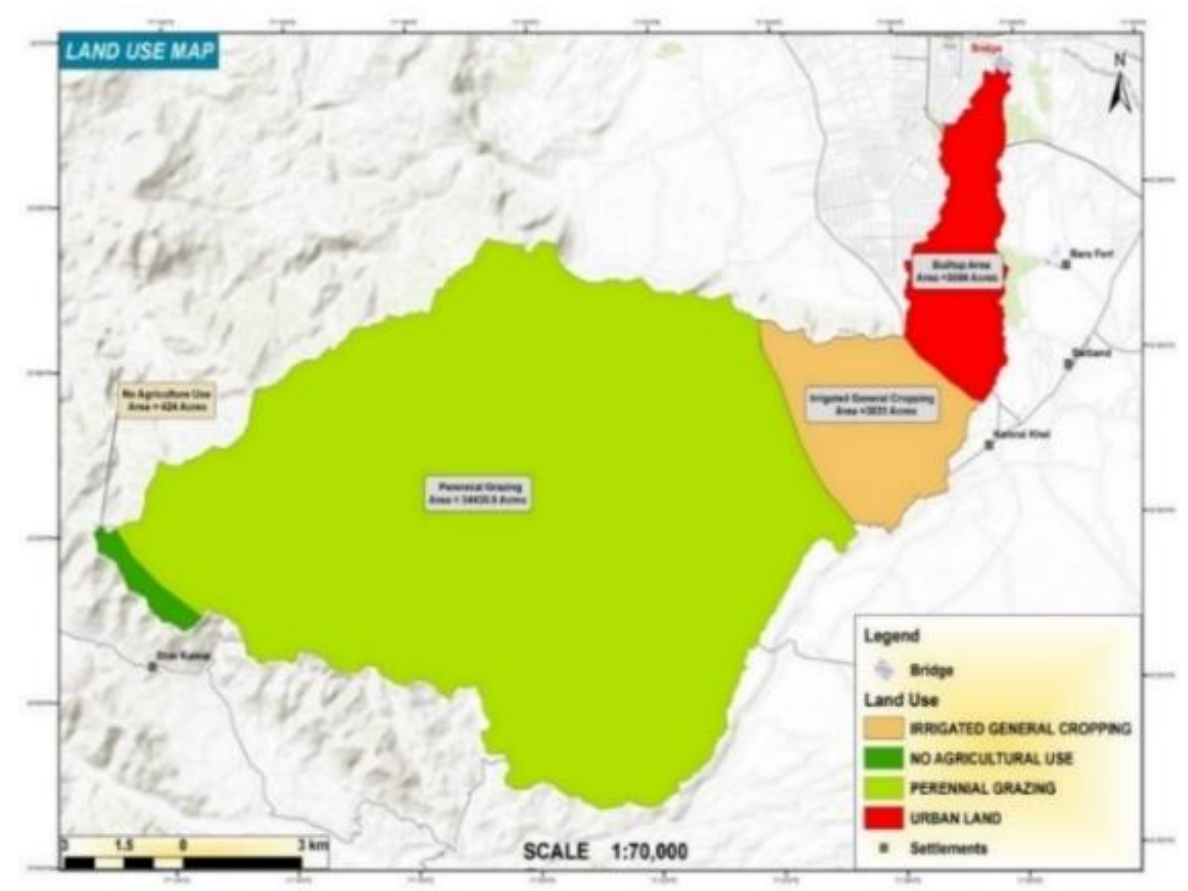

Fig. 2. Tajabad Khwar land use map for catchment area

Hydrologic soil groups B and C were found. Individual area curve number (CN) was obtained based on Soil type, land use, land cover and Antecedent soil moisture (AMC) condition NCRS (U.S. national resources conservation service) Curve Number Tables available online. Since in study area the condition are average conditions that why the curve number based AMCII condition was used directly from the tables. Based on the individual $\mathrm{CN}$ and corresponding area, weighted $\mathrm{CN}$ was calculated and was found to be 76 . These calculations are shown in Table 1.

Table 1

Tajabad Khwar catchment land use cover and CN

\begin{tabular}{lllllll}
\hline Land USE & \multicolumn{7}{l}{ Curve Number for Hydrologic Soil Group } \\
\cline { 2 - 7 } & $\mathrm{C}$ & & \multicolumn{7}{c}{ B } & & \\
& Area & $\mathrm{CN}$ & $\mathrm{A} \times \mathrm{CN}$ & Area & $\mathrm{CN}$ & $\mathrm{A} \times \mathrm{CN}$ \\
Coniferous forest and Grazing & 55.7 & 79 & 65.12 & 83.6 & 69 & 56.87 \\
Irrigated General Cropping & 6.2 & 82 & 7.52 & 9.3 & 75 & 6.88 \\
Urban Land & 5.0 & 89 & 6.58 & 7.49 & 92 & 6.8 \\
Non-Agricultural Land & 0.69 & 91 & 0.92 & 1.03 & 86 & 0.87 \\
Total & 67.6 & & 80.1 & 101.4 & & 71.4 \\
Curve Number $(\mathrm{CN})=(\mathrm{C}+\mathrm{B}) / 2=76$ & & & & & & \\
\hline
\end{tabular}


Estimation of Time of concentration (Tc) using Kirpich's formula as given below in Eq. (1).

$$
T c=\left[\frac{11.9 L^{3}}{H}\right]^{0.385}
$$

$\mathrm{L}=$ Longest length of a stream

$\mathrm{H}=$ Difference in altitude of the stream at start and end

Both the perimeters used in the Kirpichs formula $\mathrm{L}$ and $\mathrm{H}$ were calculated by using the DEM model for the catchment area in ArcGIS software which was $16909.32 \mathrm{~m}$ and $1483.38 \mathrm{~m}$ respectively. The time of concentration was calculated to be 1.47 hours. Rainfall frequency analysis was carried out using Value Type I distribution (Gumbel Extreme) in order to predict of maximum depth of daily rainfall for different Return Periods (RP). The daily maximum rainfall data for District Peshawar for the time period of 1973-2018 was used as illustrated in Table 2.

Table 2
Different Return Periods Daily
\begin{tabular}{lll} 
RP (Years) & Peshawar (inches) & Peshawar $(\mathrm{mm})$ \\
\hline 10 & 4.59 & 116.58 \\
20 & 5.46 & 138.68 \\
50 & 6.59 & 167.38 \\
100 & 7.44 & 188.97 \\
500 & 9.39 & 238.50 \\
\hline
\end{tabular}

After computing all the relevant data, the estimation of the design flood was done using HECHMS software. The inputs included the following data:
i. Precipitation of Different Return Period
ii. Catchment Area
iii. Curve Number
iv. Time of concentration

NRCS Curve Number Method was used for the generation of Unit Hydrographs for each return period with a control specification of 30 minutes time interval and keeping 24 hours for each run. For each return period flow, the obtained flood values were adopted for downstream routing and calculation of water level as shown in Table 3 below.

\section{Table 3}

Maximum discharge of flood for Different Period of return taken from HEC-HMS

\begin{tabular}{|c|c|c|c|c|c|c|}
\hline \multirow[t]{2}{*}{ S. No } & \multirow[t]{2}{*}{ Area of study } & \multirow{2}{*}{$\begin{array}{l}\text { Watershed area } \\
\text { (sq miles) }\end{array}$} & \multicolumn{4}{|c|}{ Discharge of Flood for Return Period $\left(\mathbf{m}^{3} / \mathbf{s e c}\right)$} \\
\hline & & & 10 & 20 & 50 & 100 \\
\hline 1 & Tajabad Khwar & 65.30 & 772 & 1036 & 1392 & 1666 \\
\hline
\end{tabular}




\section{Results}

\subsection{Water Surface Elevation Estimation Using HEC RAS}

Hydraulic Engineering Centre River Analysis Simulation (HEC-RAS) is a hydraulic model that can be used for flood plain development of different natural and manmade channels. It requires geometry of river cross-section, flow data, and roughness details. In this study too HEC-RAS was used as follows.

As discussed above, 30 cross-sections were obtained from the topographic map using Arc GIS. Similarly, flood discharges were also estimated using HEC-HMS for four different Return periods. This data along with roughness coefficient and boundary condition was used as input into the hydraulic model to estimate the water surface elevation and the corresponding flood plain. The schematic diagram of the study reach in HEC-RAS is shown in Figure 3.

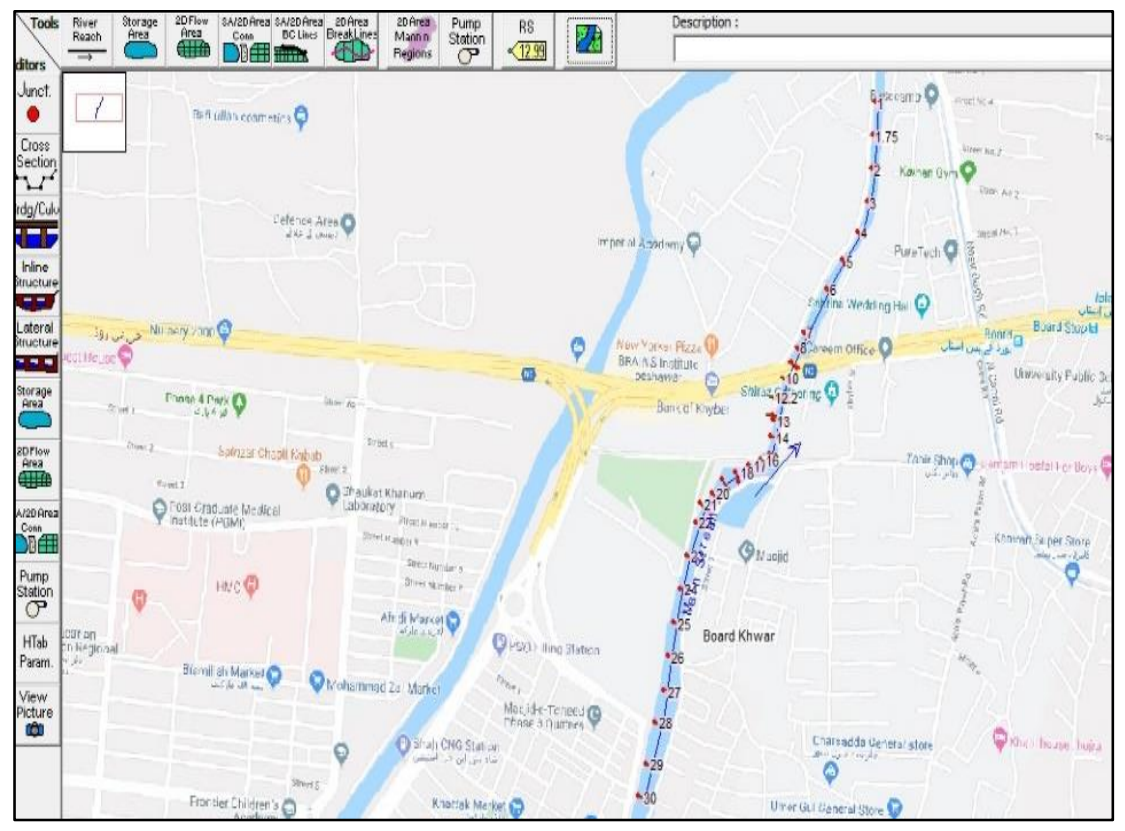

Fig. 3 HEC-RAS schematic figure of data of Tajabad Khwar geometry

Manning roughness coefficient of 0.035 was used based upon the land use details and bed characteristics which comprise of a rough surface having coarse and gravely bed material. Normal water depth was taken as flow boundary conditions for steady-state analysis at upstream and critical flow for downstream of khwar. Similarly, for the performance of unsteady flow analysis upstream the boundary condition was assumed as the flow hydrographs which were imported from HEC-HMS as explained previously and at downstream normal depth was used as a boundary condition.

The model as shown in Figure 4 was then simulated for each of the return periods and the results which were obtained are shown in Table 4 below, the corresponding water surface elevation along the representative cross-section is shown in Figure 5 while the same along the longitudinal profile is shown in Figure 6. 


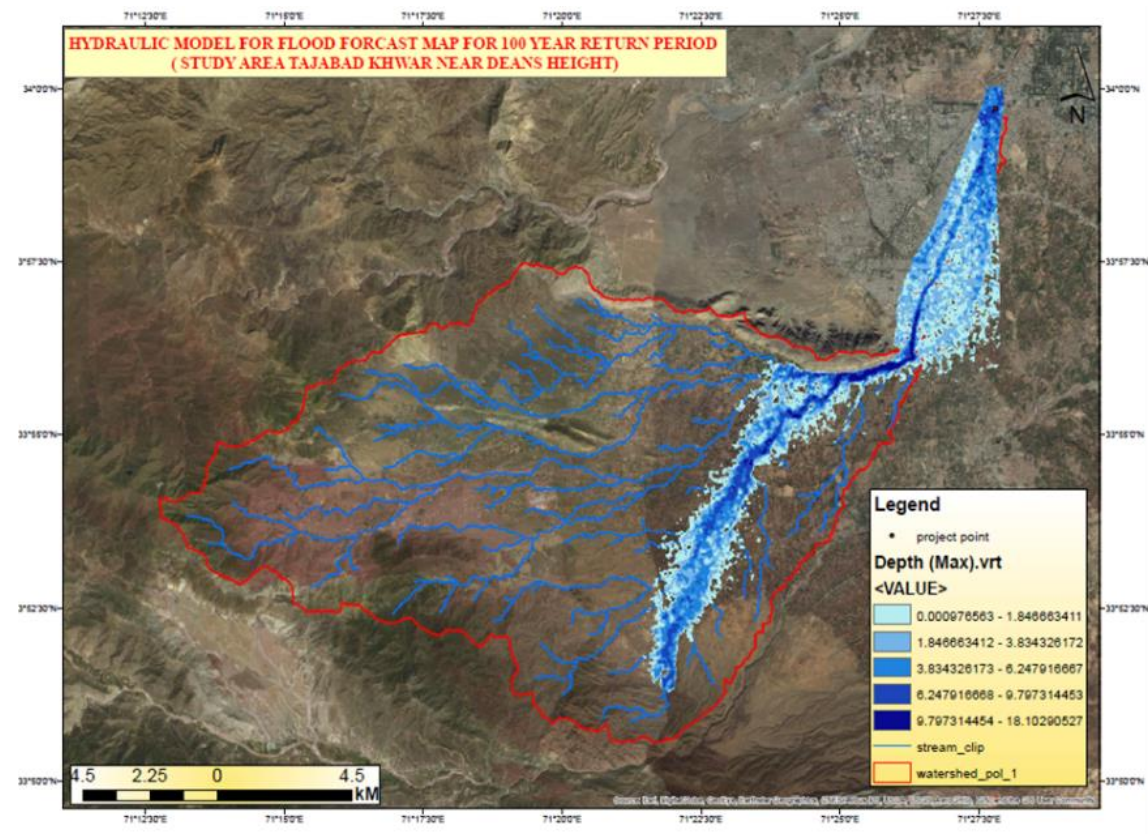

Fig. 4 Map for flow depth of 100 Year Period of Return using Arc GIS

\section{Table 4}

Water surface elevation for flood discharge corresponding to each return period using HEC-RAS

\begin{tabular}{lll}
\hline W.S.E. & & \\
\hline R.P (Yrs) & Avg $(\mathrm{m})$ & Max $(\mathrm{m})$ \\
10 & 196.00 & 197.00 \\
20 & 197.00 & 199.00 \\
50 & 199.00 & 201.00 \\
100 & 200.00 & 202.00 \\
\hline
\end{tabular}

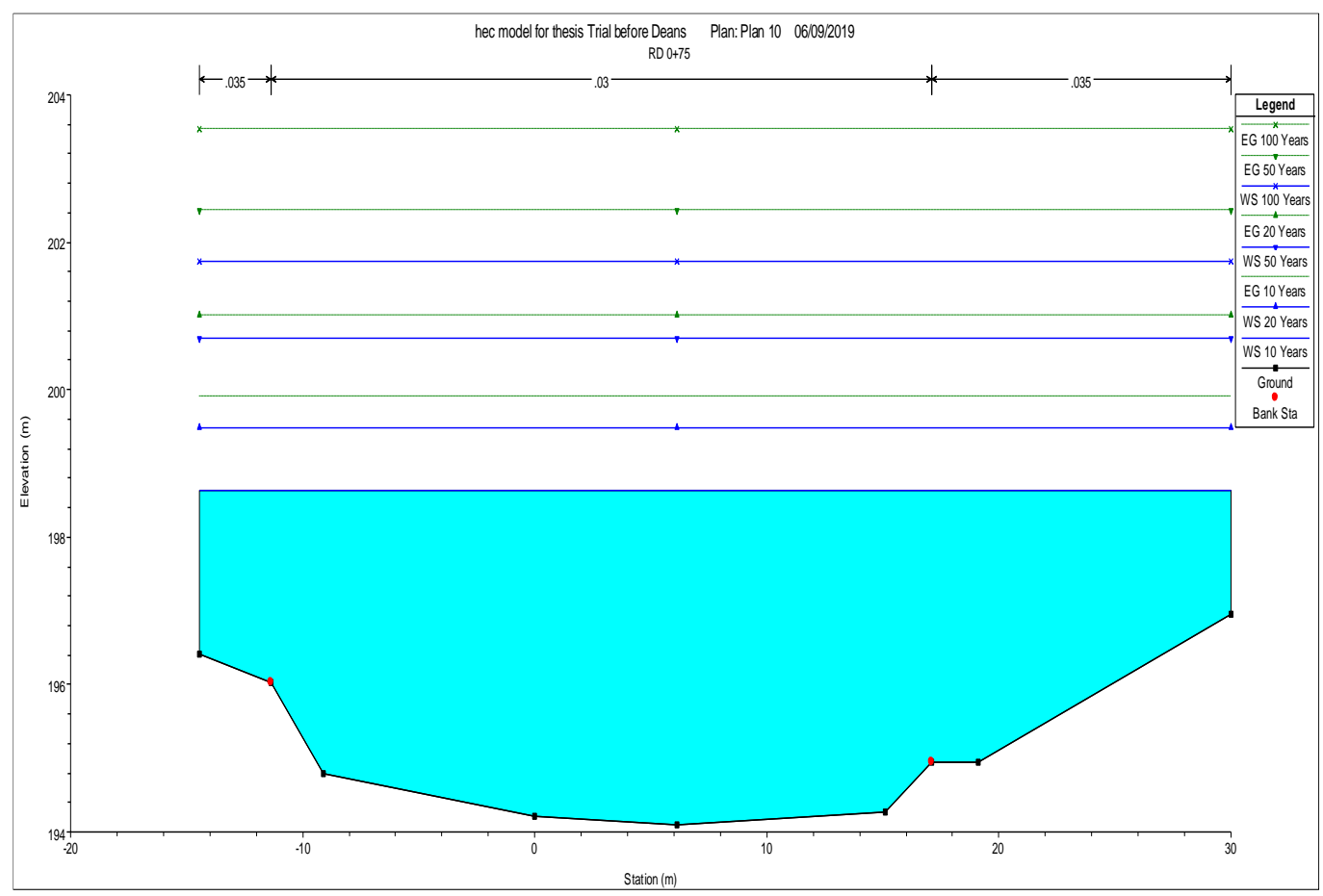

Fig. 5. W.S.E Plot at Section adjacent to Deans Apartment for selected periods of return 


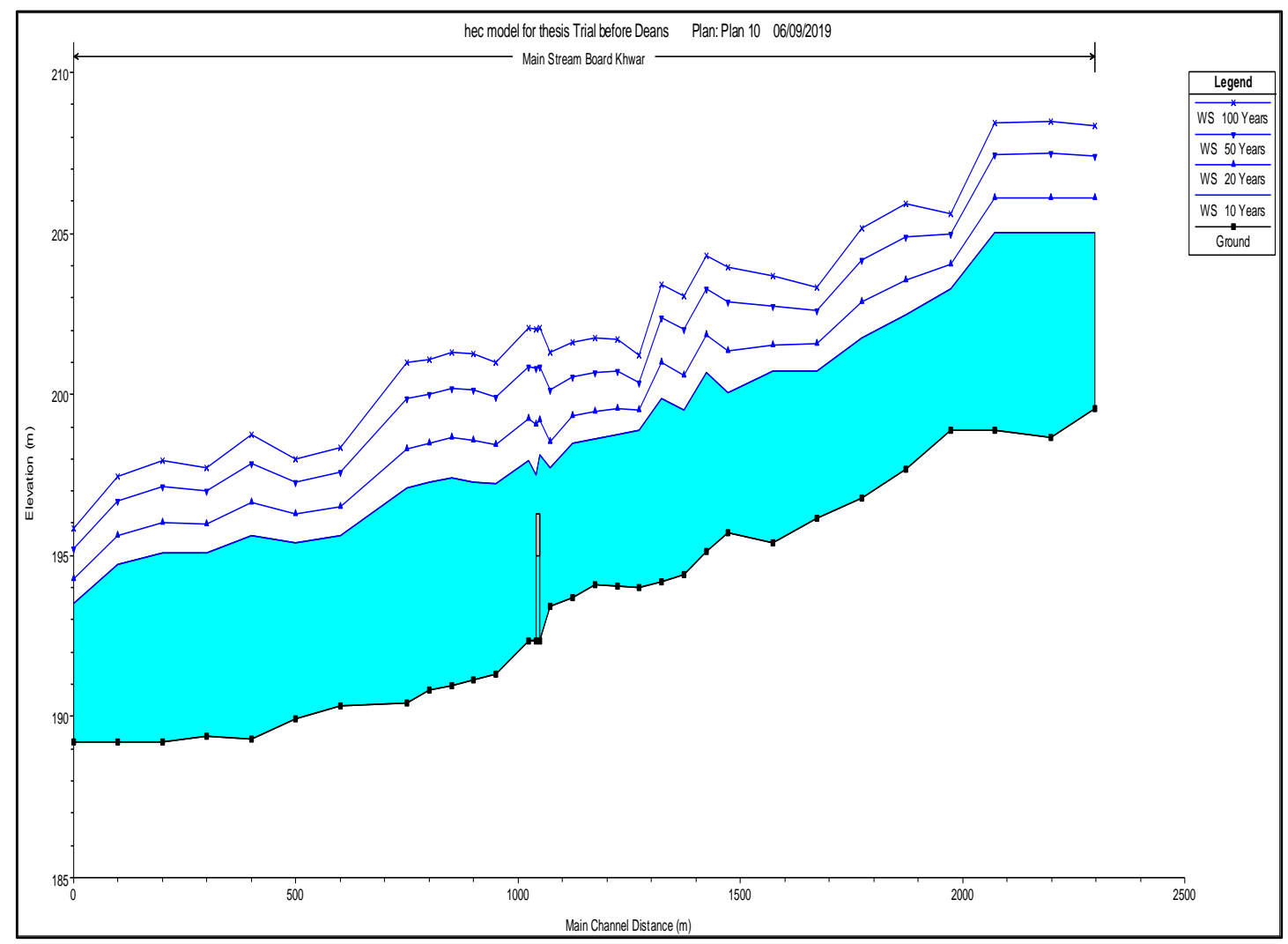

Fig. 6. Each Return Period Longitudinal Profile (W.S.E)

\subsection{Flood Zone Mapping of Tajabad Khwar (Natural Waterway) Near Deans Residential Apartment}

Demarcation of contour maps plotted on Civil 3D was carried out Based upon the results of the Steady Flow Analysis performed on HEC RAS Software for the identification of the limits of the flood inundation for 100-year return period flood event. Three different types of flood zone maps were generated including maximum water surface elevation, averaged separately for up-stream and down-stream cross-section and average water surface elevation, for 100 years return period as shown in Figure 7- 9 respectively. These figures show the extent of the area to be affected due to 100 years return period flood. Maximum water surface elevation is resulting in the most devastating flood and will result in flooding of all the surrounding areas as is shown in Figure 6. Similarly, for the other two cases, the submergence of the surrounding area is smaller as compared to the maximum conditions. But even if we take average water surface elevation, for 100 years return period flood, the first two stories of the Dean apartment will be submerged in water as is clear from Figure 8. 


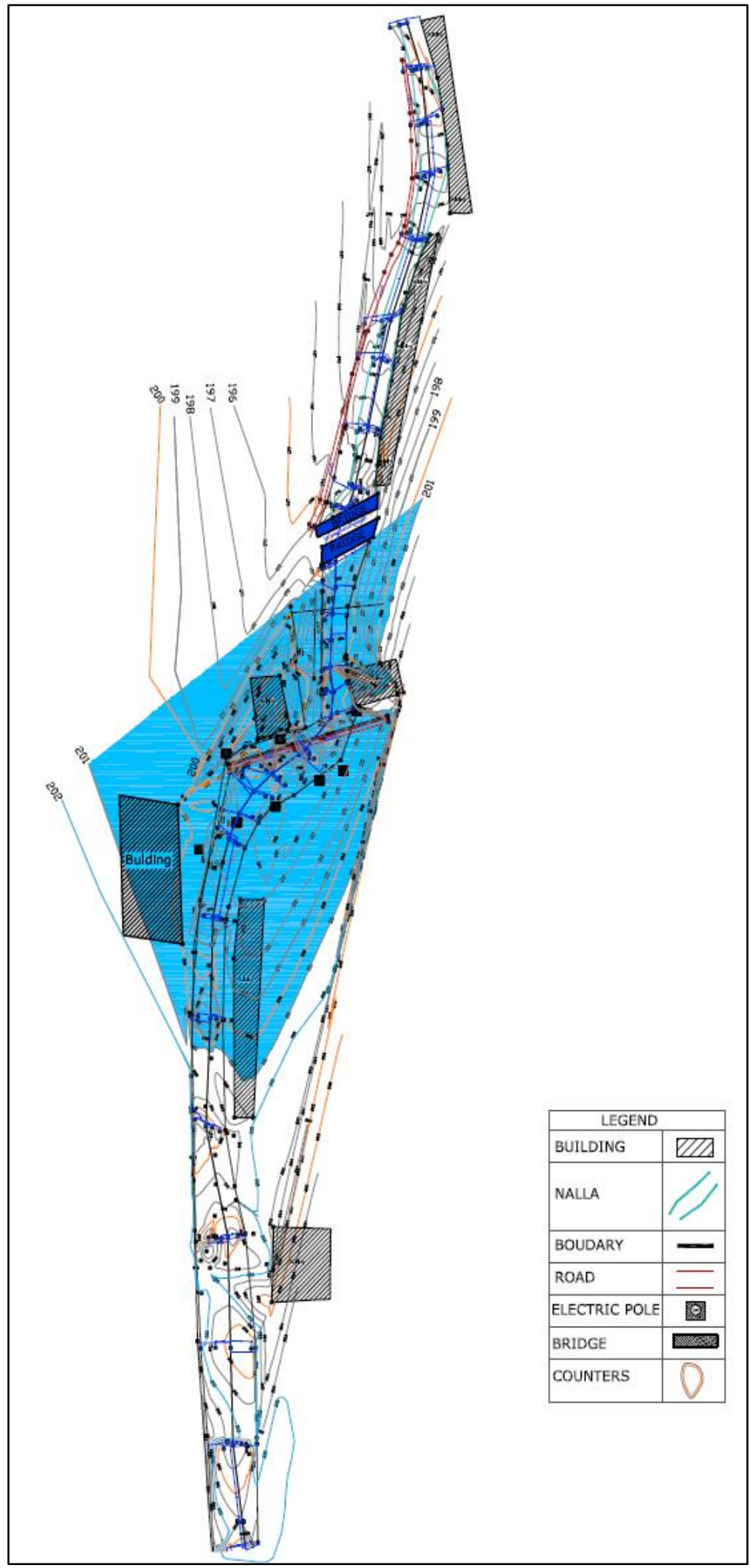

Fig. 7. Flood Zone Map (Maximum W.S.E) for a 100-year period 


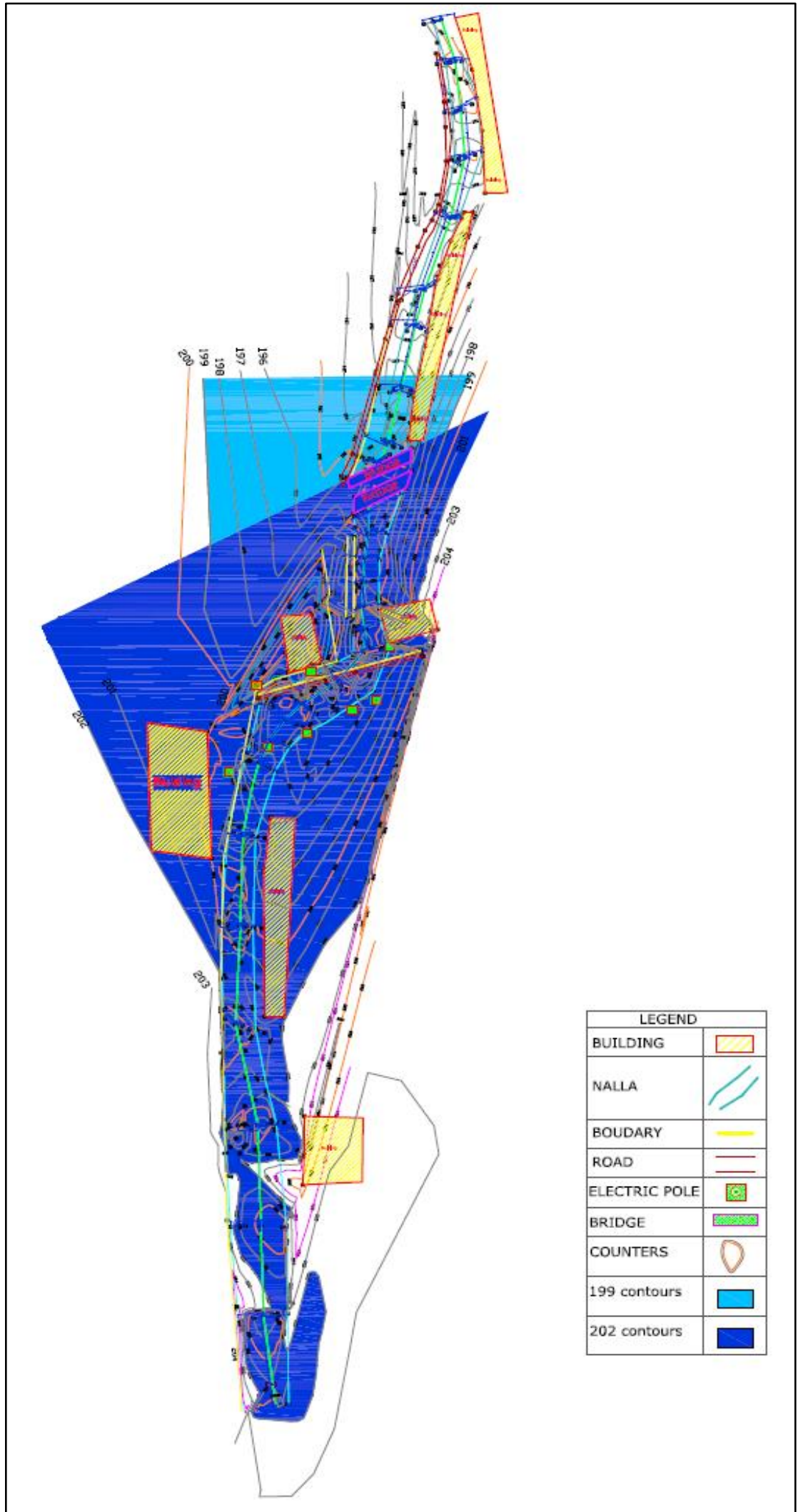

Fig. 8. Map of Flood Zone (u/s \& d/s average W.S.E) of 100-year period 


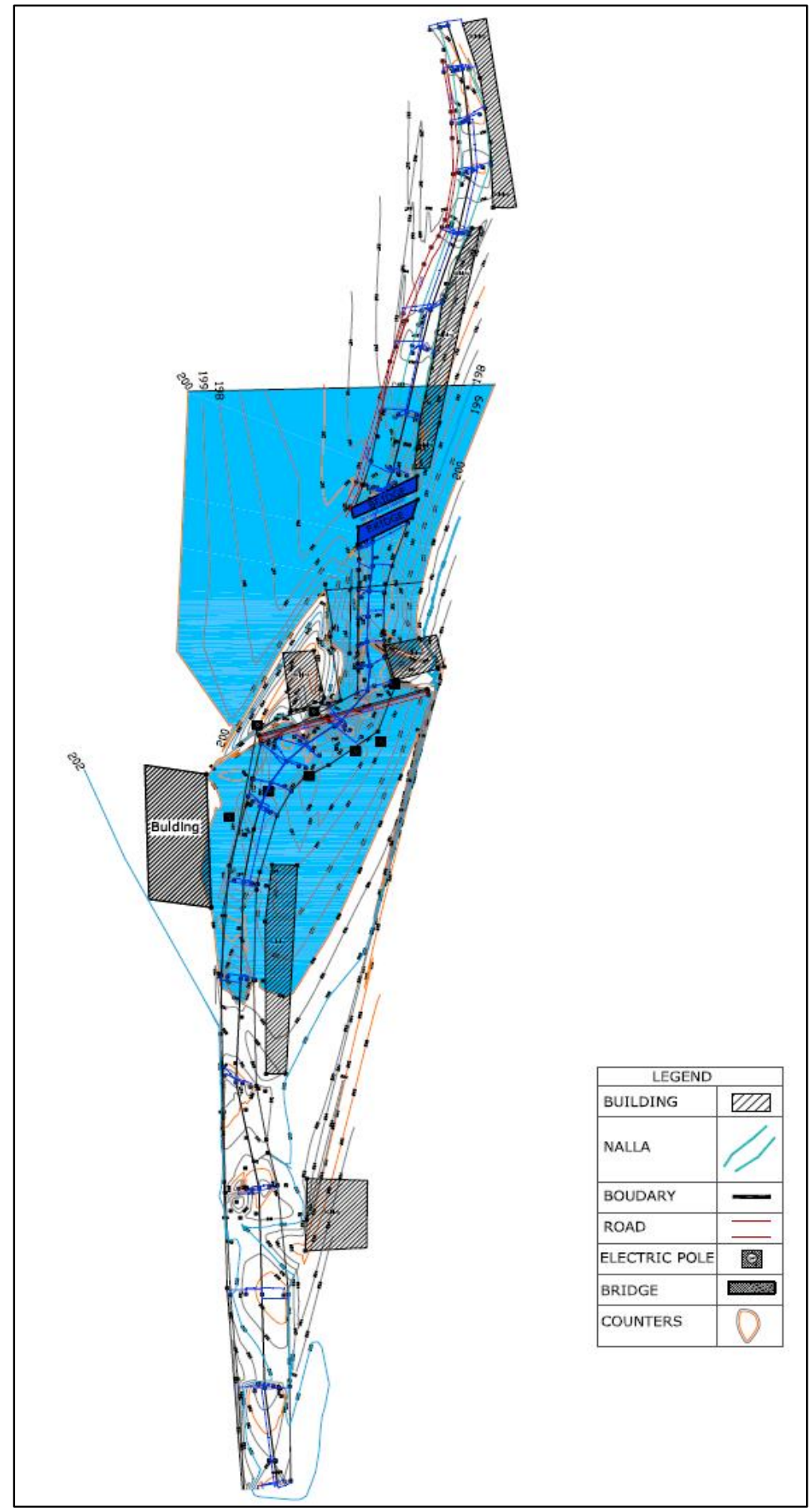

Fig. 9. Map of Flood Zone (Maximum W.S.E) for 100-year period

\subsection{Authentication of Maps Generated for Flood Zone}

As the design life for a building is normally taken to be 100 years, therefore, Flood zone map for the return of 100-year is considered to be most important among all other generated maps. The validation of the flood zone map was done through maps generated from HEC RAS 2D Hydraulic modeling (Unsteady analysis) performed on HEC RAS software and from the map generated through combine HEC GeoRAS (ArcGIS extension) and HEC RAS 1 Dimensional hydraulic model. The result obtained was quite supportive as the extent of flood inundation was the same in all the three maps 
as shown in Figure 10 and Figure 11 for HEC RAS 2D and Arc GIS respectively, which implies that the flood zone maps generated in the research are correct and can be utilize for future flood forecasting near Tajabad Khwar when the area is subjected to the amount of rainfall used in the research.

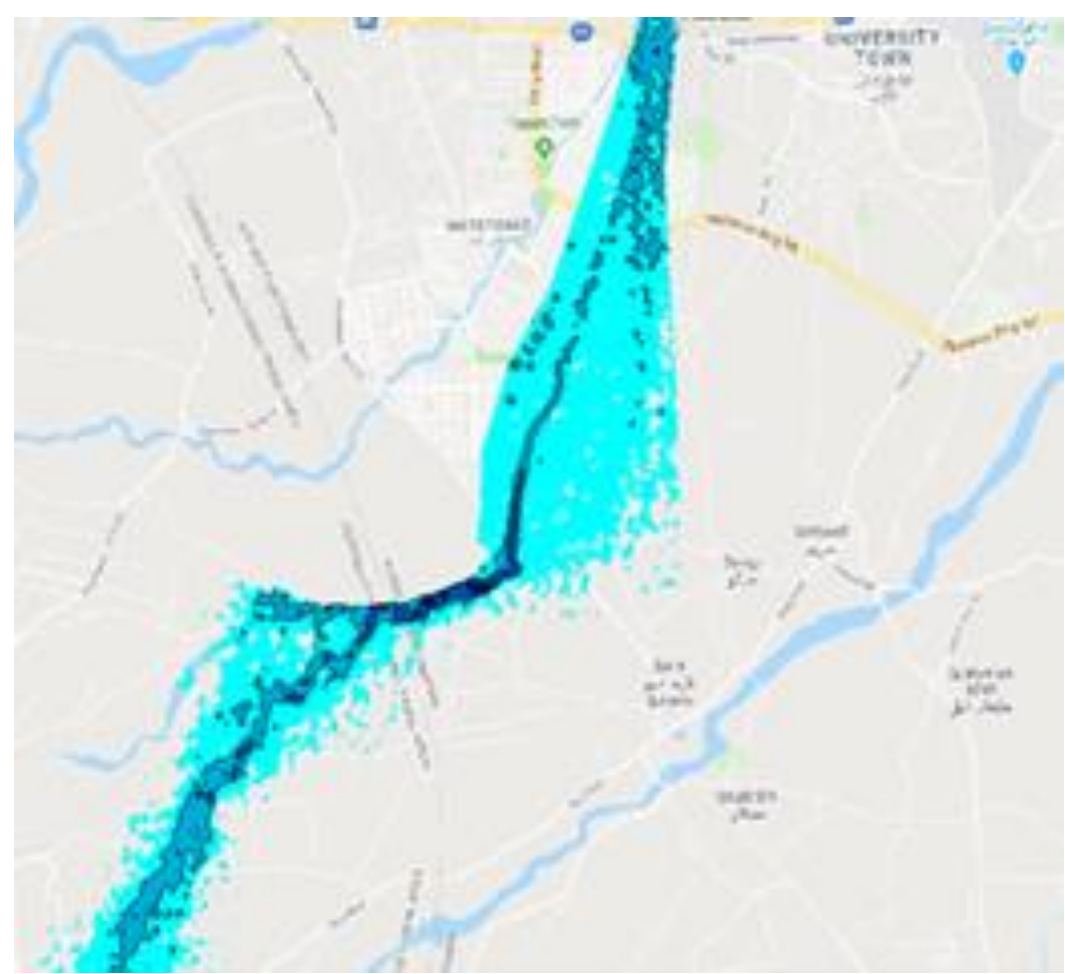

Fig. 10. Tajabad catchment flood zone map for 100-year flood (Unsteady Flow Analysis)

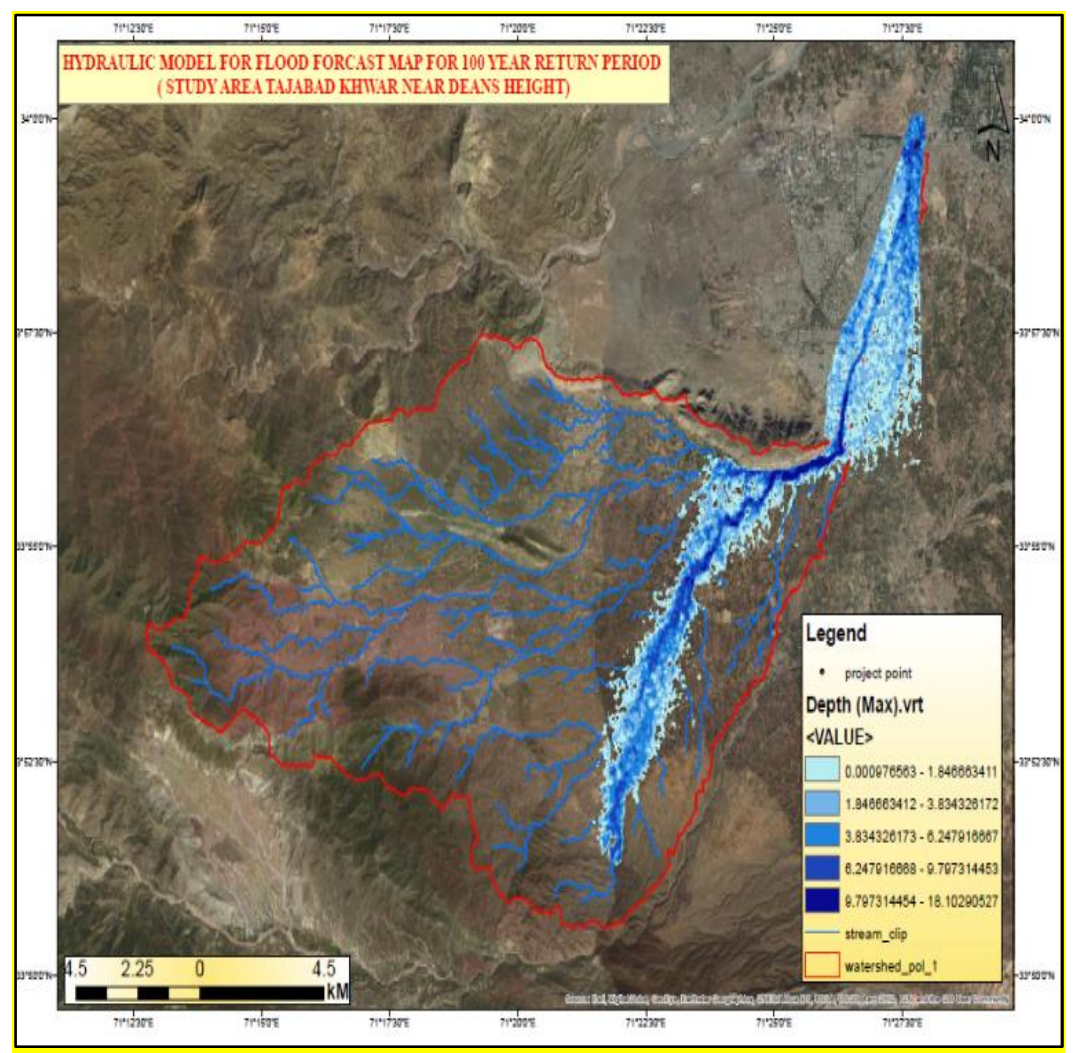

Fig. 11. Arc-GIS flow depth map for 100 -year flood 


\section{Conclusions}

The main focus of this research study is on the application of HEC-HMS (Hydrological Modelling) and HEC-RAS (Hydraulic Modelling) for estimation of peak flood and most vulnerable area identification likely to be submerged, in order to determine the extent of flood risk. For different return periods, the HEC-RAS model was developed for the assessment of flood inundation for the Tajabad Khwar (Natural Waterway) adjacent to Deans Apartment. From the overall analysis of the model, it's been evident that the elevations of water surface for the maximum estimated flood of 100 Yrs. Return Period is 1666.00 cumecs $\left(\mathrm{m}^{3} / \mathrm{s}\right)$. This will occur at 201 Meters cross-section level of Deans Apartment. The elevation of top level is $202 \mathrm{~m}$, the model shows that the apartment will be greatly affected if similar flooding events occurs. Result was also verified through Arc GIS and HEC RAS 2D Analysis which further proves the results. The water restriction due to encroachments made in the waterway of the flash flood cause pounding of water at the upstream suburban areas at Tajabad and Phase 3 Hayatabad where the base level of the residentiaries is at the risk level resulting in complete submergence of the entire localities. The same result is validated by generating flood map through Civil-3D, using Unsteady HEC-RAS Analysis and also using Arc-GIS.

On the basis of this research, it is recommended to carry out such flood mapping using HEC RAS for all other khwar/Nullah to avoid loss of life and property in the surrounding area. This model can also be used to develop a real-time flood forecasting map of other Khwar or nullah for daily observed discharge which has the ability to issue timely flood warnings in the case when the discharge exceeds the capacity of the nullah.

\section{Acknowledgement}

The authors of this research work acknowledged the Professors of Civil Engineering Department UET Peshawar, for their kind ideas, suggestions, and assistance. Also, the authors of this work are greatly thankful for technical staff of AD LG\&RDD Peshawar for their support in the collection of data.

\section{References}

[1] Aerts, Jeroen, David C. Major, Malcolm J. Bowman, Piet Dircke, and M. Aris Marfai. Connecting delta cities: coastal cities, flood risk management and adaptation to climate change. 2009.

[2] Ahmad, Afnan, Shahid Ali, Mujahid Khan, Indra Sati Hamonangan Harahap, and Muhammad Sagheer Aslam. "ReAssessment of an Earth fill Dam using Finite Element Method and Limit Equilibrium Method (Case study of Latamber Dam, Pakistan)." Journal of Advanced Research in Fluid Mechanics and Thermal Sciences 71, no. 2 (2020): 87-102. https://doi.org/10.37934/arfmts.71.2.87102

[3] De Wrachien, D., and Stefano Mambretti. "Mathematical models in flood management: overview, laboratory tests and case study." Flood Risk Assessment and Management 1 (2012): 11. https://doi.org/10.2495/978-1-84564-646$\underline{2 / 02}$

[4] Han, Dawei. Flood risk assessment and management. Bentham Science Publishers, 2011.

[5] Burby, Raymond J. "Flood insurance and floodplain management: the US experience." Global Environmental Change Part B: Environmental Hazards 3, no. 3 (2001): 111-122. https://doi.org/10.3763/ehaz.2001.0310

[6] Aronica, G., B. Hankin, and K. Beven. "Uncertainty and equifinality in calibrating distributed roughness coefficients in a flood propagation model with limited data." Advances in water resources 22, no. 4 (1998): 349-365. https://doi.org/10.1016/S0309-1708(98)00017-7

[7] Jayawardena, Amithirigala Widhanelage. "Rainfall-runoff modelling." In Fluid Mechanics, Hydraulics, Hydrology and Water Resources for Civil Engineers, pp. 559-587. CRC Press. https://doi.org/10.1201/9780429423116-33

[8] Jia, Yangwen, Hongli Zhao, Cunwen Niu, Yunzhong Jiang, Hong Gan, Zhi Xing, Xueli Zhao, and Zhixin Zhao. "A WebGIS-based system for rainfall-runoff prediction and real-time water resources assessment for Beijing." Computers \& Geosciences 35, no. 7 (2009): 1517-1528. https://doi.org/10.1016/j.cageo.2008.10.004

[9] Floodplain zoning. Technical Workshop on Nonstructural flood management.

[10] Garrote, Luis, and Rafael L. Bras. "A distributed model for real-time flood forecasting using digital elevation models." Journal of Hydrology 167, no. 1-4 (1995): 279-306. https://doi.org/10.1016/0022-1694(94)02592-Y 
[11] Tassew, Bitew G., Mulugeta A. Belete, and K. Miegel. "Application of HEC-HMS model for flow simulation in the Lake Tana basin: The case of Gilgel Abay catchment, upper Blue Nile basin, Ethiopia." Hydrology 6, no. 1 (2019): 21. https://doi.org/10.3390/hydrology6010019

[12] Shayannejad, M., K. Ostad-Ali-Askari, S. Eslamian, V. P. Singh, and N. R. Dalezios. "Analyzing of Flow in Open channels networks using HEC-RAS." J. Ecol. Nat. Res 2, no. 4 (2018): 1-7. https://doi.org/10.23880/jenr-16000136

[13] Husain, Azhar. "Flood Modelling by using HEC-RAS." International Journal of Engineering Trends and Technology 50, no. 1 (2017): 1-7. https://doi.org/10.14445/22315381/ijett-v50p201

[14] Ahmad, Hakim Farooq, Akhtar Alam, M. Sultan Bhat, and Shabir Ahmad. "One Dimensional Steady Flow Analysis Using HECRAS-A case of River Jhelum, Jammu and Kashmir." Eur. Sci. J 12 (2016): 340-350. https://doi.org/10.19044/esj.2016.v12n32p340

[15] Myrland, Johanna. "Two-dimensional hydraulic modeling for flood assessment of the Rio Rocha, Cochabamba, Bolivia." (2014).

[16] Malik, Muhammad Irfan, and F. Ahmad. "Flood inundation mapping and risk zoning of the Swat River Pakistan using HEC-RAS model." Lasbela Univ J Sci Technol 3 (2014): 45-52.

[17] Aziz, A. "Rainfall-runoff modeling of the trans-boundary Kabul River basin using Integrated Flood Analysis System (IFAS)." Pakistan Journal of Meteorology 10, no. 20 (2014): 75-81.

[18] Mudabeti, A. M., and K. B. Mfundisi. "Development of a hydraulic model for the Kavango river for improved disaster risk management in Namibia." Journal of Environmental Science and Water Resources 2, no. 9 (2013): 310-319.

[19] Kardavani, Parviz, and Mohammad Hossein Qalehe. "Efficiency of hydraulic models for flood zoning using GIS (Case Study: Ay-Doghmush River Basin)." Life Science Journal 10, no. 2 (2013).

[20] Khan, M. A., Z. Mustaffa, A. L. B. Balogun, M. A. M. Al-Bared, and A. Ahmad. "Role of the Rheological Parameters in Debris Flow Modelling." In IOP Conference Series: Materials Science and Engineering, vol. 1092, no. 1, p. 012041. IOP Publishing, 2021. https://doi.org/10.1088/1757-899x/1092/1/012041

[21] Noor, Muqadas, Humaira Arshad, Mujahid Khan, Mahmood Alam Khan, Muhammad Sagheer Aslam, and Afnan Ahmad. "Experimental and HEC-RAS Modelling of Bridge Pier Scouring." Journal of Advanced Research in Fluid Mechanics and Thermal Sciences 74, no. 1 (2020): 119-132. https://doi.org/10.37934/arfmts.74.1.119132 